\title{
Ruthenium(II) complexes containing bidentate Schiff bases and triphenylphosphine or triphenylarsine
}

\author{
P VISWANATHAMURTHI ${ }^{\mathrm{a}}, \mathrm{R}_{\text {KARVEMBU }}^{\mathrm{b}}, \mathrm{V}$ THARANEESWARAN ${ }^{\mathrm{b}}$ and \\ K NATARAJAN ${ }^{\mathrm{c} *}$ \\ ${ }^{a}$ Department of Chemistry, Periyar University, Salem 636 011, India \\ ${ }^{\mathrm{b}}$ Department of Chemistry (PG), Kongunadu Arts and Science College, Coimbatore 641 029, India \\ ${ }^{\mathrm{c}}$ Department of Chemistry, Bharathiar University, Coimbatore 641 046, India \\ e-mail: k_natraj6@yahoo.com
}

MS received 6 November 2004; revised 19 March 2005

\begin{abstract}
Reactions of ruthenium(II) complexes $\left[\mathrm{RuHX}(\mathrm{CO})\left(\mathrm{EPh}_{3}\right)_{2}(\mathrm{~B})\right]\left(\mathrm{X}=\mathrm{H}\right.$ or $\mathrm{Cl} ; \mathrm{B}=\mathrm{EPh}_{3}$, pyridine (py) or piperidine (pip); $\mathrm{E}=\mathrm{P}$ or As) with bidentate Schiff base ligands derived by condensing $o$ hydroxyacetophenone with aniline, $o$ - or $p$-methylaniline have been carried out. The products were characterized by analytical, IR, electronic and ${ }^{1} \mathrm{H}-\mathrm{NMR}$ spectral studies and are formulated as $[\mathrm{Ru}(\mathrm{X})(\mathrm{CO})$ $\left.(\mathrm{L})\left(\mathrm{EPh}_{3}\right)(\mathrm{B})\right]\left(\mathrm{L}=\right.$ Schiff base anion; $\mathrm{X}=\mathrm{H}$ or $\mathrm{Cl} ; \mathrm{B}=\mathrm{EPh}_{3}$, py or pip; $\mathrm{E}=\mathrm{P}$ or As $)$. An octahedral structure has been tentatively proposed for the new complexes. The new complexes were tested for their catalytic activities in the oxidation of benzyl alcohol to benzaldehyde.
\end{abstract}

Keywords. Monobasic bidentate; Schiff bases; ruthenium(II) complexes; spectral studies; triphenyl phosphine.

\section{Introduction}

There has been considerable current interest in the chemistry of ruthenium, ${ }^{1}$ primarily because of the fascinating electron-transfer, photochemical and catalytic properties exhibited by the complexes of this metal. As the coordination environment around the central metal ion directs properties of the complexes, complexation of ruthenium by ligands of different types has been of significant importance. RutheniumSchiff base complexes, particularly those containing oxygen and nitrogen as donor atoms were found to be very efficient catalysts in the oxidation of alcohols using N-methylmorpholine-N-oxide as co-oxidant. ${ }^{2-5}$

As a part of our continuing efforts to synthesis and characterise ruthenium chelates using simple and inexpensive Schiff base ligands, in this paper, we describe the synthesis, characterisation and catalytic studies of stable ruthenium(II) complexes. The general structure of the Schiff base ligands used in this study is shown in scheme 1 .

\section{Experimental}

$\mathrm{RuCl}_{3} .3 \mathrm{H}_{2} \mathrm{O}$ was purchased from Loba-Chemie and used as supplied. Solvents were purified according

\footnotetext{
*For correspondence
}

to standard procedures. ${ }^{6}$ Elemental analyses were performed at Central Drug Research Institute, Lucknow, India. IR spectra were recorded in $\mathrm{KBr}$ pellets with a Shimadzu FT-IR spectrophotometer in the 4000$450 \mathrm{~cm}^{-1}$ range. Electronic spectra were recorded in $\mathrm{CH}_{2} \mathrm{Cl}_{2}$ solution with a Systronics spectrophotometer in the $800-200 \mathrm{~nm}$ range. ${ }^{1} \mathrm{H}-\mathrm{NMR}$ spectra were recorded on a Bruker WM 400 instrument using tetramethyl silane (TMS) as internal standard. Melting points were recorded on a Boetius microheating table and are uncorrected.

The precursor complexes $\left[\mathrm{RuHCl}(\mathrm{CO})\left(\mathrm{PPh}_{3}\right)_{3}\right]{ }^{7}$ $\left[\mathrm{RuH}_{2}(\mathrm{CO})\left(\mathrm{PPh}_{3}\right)_{3}\right],{ }^{7}\left[\mathrm{RuHCl}(\mathrm{CO})\left(\mathrm{AsPh}_{3}\right)_{3}\right],{ }^{8}[\mathrm{RuHCl}$ $\left.(\mathrm{CO})\left(\mathrm{PPh}_{3}\right)_{2}(\mathrm{py})\right]^{9}$ and $\left[\mathrm{RuHCl}(\mathrm{CO})\left(\mathrm{PPh}_{3}\right)_{2}(\mathrm{pip})\right]^{9}$ and the Schiff base ligands ${ }^{10}$ were prepared according to

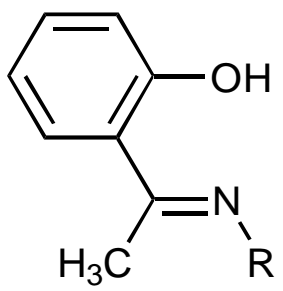

$$
\begin{gathered}
{\left[\mathrm{R}=\mathrm{Ph}\left(\text { Hohyac-an); } 2-\mathrm{MeC}_{6} \mathrm{H}_{4}\right. \text { (Hohyac-oman); }\right.} \\
\text { 4- } \left.\mathrm{MeC}_{6} \mathrm{H}_{4} \text { (Hohyac-pman) }\right]
\end{gathered}
$$

Scheme 1. General structure of the Schiff base ligand. 
published procedures. The procedure for catalytic oxidation is similar to that reported in our earlier paper. ${ }^{11}$

\subsection{Preparation of new ruthenium(II) complexes, $\left[R u(X)(C O)(L)\left(E P h_{3}\right)(B)\right]$}

To a solution of $\left[\mathrm{RuHX}(\mathrm{CO})\left(\mathrm{EPh}_{3}\right)_{2}(\mathrm{~B})\right][\mathrm{X}=\mathrm{H}$ or $\mathrm{Cl} ; \mathrm{B}=\mathrm{EPh}_{3}$, pyridine (py) or piperidine (pip); $\mathrm{E}=\mathrm{P}$ or As] $(0.1 \mathrm{~g}, 0.1-0.13 \mathrm{mmol})$ in benzene $(25 \mathrm{ml})$, was added the appropriate Schiff base (0.021-0.051 g, 0.1-0.13 mmol) (molar ratio of ruthenium complex: Schiff base was $1: 1)$. The solution was heated under reflux for $6 \mathrm{~h}$. Then, it was concentrated to a small volume $(3 \mathrm{ml})$ and the new complex $\left[\mathrm{Ru}(\mathrm{X})(\mathrm{CO})(\mathrm{L})\left(\mathrm{EPh}_{3}\right)(\mathrm{B})\right](\mathrm{L}=$ Schiff base anion) was separated from it by the addition of a small quantity $(6 \mathrm{ml})$ of light petroleum $\left(60-80^{\circ} \mathrm{C}\right)$. The product was filtered, washed with light petroleum and recrystallised from $\mathrm{CH}_{2} \mathrm{Cl}_{2} /$ light petroleum (60$80^{\circ} \mathrm{C}$ ) mixture and dried in vacuo (Yields: $71-80 \%$ ).

\section{Results and discussion}

New hexa-coordinated ruthenium(II) complexes of the type $\left[\mathrm{Ru}(\mathrm{X})(\mathrm{CO})(\mathrm{L})\left(\mathrm{EPh}_{3}\right)(\mathrm{B})\right](\mathrm{L}=$ Schiff base anion; $\mathrm{X}=\mathrm{H}$ or $\mathrm{Cl} ; \mathrm{B}=\mathrm{EPh}_{3}$, py or pip; $\mathrm{E}=\mathrm{P}$ or $\mathrm{As}$ ) have been prepared from the reaction between $\left[\mathrm{RuHX}(\mathrm{CO})\left(\mathrm{EPh}_{3}\right)_{2}(\mathrm{~B})\right]$ and the respective Schiff bases (molar ratio $1: 1$ ) in dry benzene as shown in scheme 2.

The analytical data of the new complexes (table 1) agree very well with the proposed molecular formula. The catalytic activity of the complexes in the oxidation of benzyl alcohol was tested in the presence of $\mathrm{N}$-methylmorpholine- $\mathrm{N}$-oxide as co-oxidant

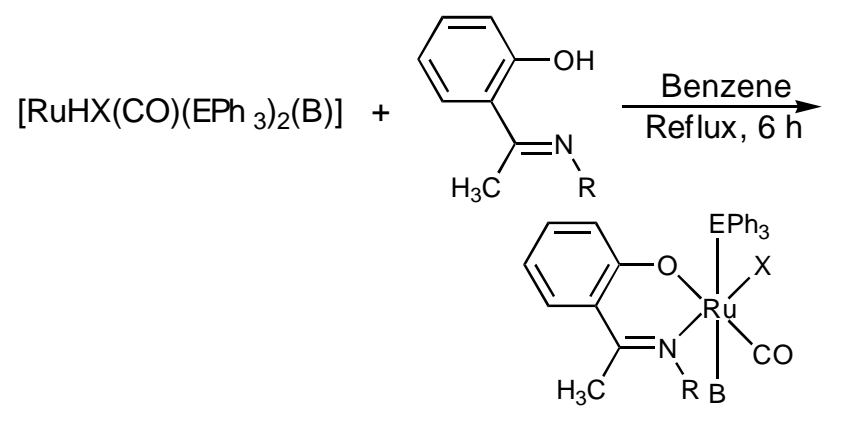

$\left(\mathrm{R}=\mathrm{Ph}, 2-\mathrm{MeC}_{6} \mathrm{H}_{4}\right.$ or $4-\mathrm{MeC}_{6} \mathrm{H}_{4} ; \mathrm{B}=\mathrm{EPh}$, py or pip; $\mathrm{E}=\mathrm{P}$ or $\mathrm{As} ; \mathrm{X}=\mathrm{H}$ or $\mathrm{Cl}$ )

Scheme 2. Formation of new ruthenium(II) complexes. and $\mathrm{CH}_{2} \mathrm{Cl}_{2}$ as solvent. There is no detectable oxidation of alcohol in the presence of N-methylmorpholine-N-oxide alone. All the synthesised rutheniumSchiff base complexes were found to catalyse the oxidation of alcohol to aldehydes but the yield and the turnover were found to vary with the different catalysts used. The percentage yield of product and turnover number range from $0 \cdot 16-5.5$ to $1 \cdot 6-55.6 \%$ respectively. The catalytic efficiency of the new ruthenium(II) complexes is lower compared to that of already reported ruthenium(II)-Schiff base complexes. ${ }^{5,11}$

\subsection{IR spectra}

In order to study the binding mode of the Schiff bases to ruthenium in the new complexes, the IR spectra of the free ligands were compared with the spectra of the ruthenium complexes. A strong band is observed at $1620-1610 \mathrm{~cm}^{-1}$ in the infrared spectra of the free Schiff bases which is characteristic of the azomethine group. If the Schiff bases coordinate through the nitrogen atom, it is expected that there must be a reduction in the azomethine frequency due to the lowering of electron density upon coordination. In the spectra of all the new complexes, this band is shifted to the region $1620-1590 \mathrm{~cm}^{-1}$ indicating the coordination of the Schiff bases through nitrogen atom. ${ }^{11}$ A strong band observed around $1270-1260 \mathrm{~cm}^{-1}$ in the free Schiff bases has been assigned to phenolic $\mathrm{C}-\mathrm{O}$ stretching. On complexation, this band has been shifted to higher frequency (1320-1300 $\mathrm{cm}^{-1}$ ) showing that the other coordination is through the phenolic oxygen atom. ${ }^{12}$ The strong absorption around $1950-1940 \mathrm{~cm}^{-1}$ has been assigned to the terminally coordinated carbonyl group in the new ruthenium complexes. In the complexes containing coordinated pyridine, ${ }^{9}$ a weak band is observed at about $1020 \mathrm{~cm}^{-1}$. The $v(\mathrm{Ru}-\mathrm{H})$ and $v(\mathrm{Ru}-\mathrm{Cl})$ absorption bands appear around $2020 \mathrm{~cm}^{-1}$ and $320 \mathrm{~cm}^{-1}$ respectively. All other characteristic bands due to triphenylphosphine and arsine are also present in the expected region.

\subsection{Electronic spectra}

The new ruthenium(II) Schiff base complexes are diamagnetic, indicating the presence of ruthenium in the +2 oxidation state. The electronic spectra of all the complexes in $\mathrm{CH}_{2} \mathrm{Cl}_{2}$ show a band in the 260$280 \mathrm{~nm}$ region. This band has been assigned to the 
Table 1. Physical characterization and analytical data of the ruthenium(II) complexes.

\begin{tabular}{|c|c|c|c|c|c|}
\hline \multirow[b]{2}{*}{ Complex } & \multirow[b]{2}{*}{ Colour } & \multirow[b]{2}{*}{ m.p./decomp. $*\left({ }^{\circ} \mathrm{C}\right)$} & \multicolumn{3}{|c|}{ Found (calculated) $(\%)$} \\
\hline & & & $\mathrm{C}$ & $\mathrm{H}$ & $\mathrm{N}$ \\
\hline$\left[\mathrm{RuCl}(\mathrm{CO})\left(\mathrm{PPh}_{3}\right)_{2}(\right.$ ohyac-an $\left.)\right]$ & Green & 153 & $68 \cdot 18(68 \cdot 02)$ & $4 \cdot 60(4 \cdot 82)$ & $1.55(1.45)$ \\
\hline$\left[\mathrm{RuCl}(\mathrm{CO})\left(\mathrm{PPh}_{3}\right)_{2}(\right.$ ohyac-oman $\left.)\right]$ & Brown & 182 & $67 \cdot 95(68 \cdot 37)$ & $4 \cdot 42(4 \cdot 85)$ & $1.25(1.53)$ \\
\hline$\left[\mathrm{RuCl}(\mathrm{CO})\left(\mathrm{PPh}_{3}\right)_{2}(\right.$ ohyac-pman $\left.)\right]$ & Green & 162 & $68 \cdot 18(68 \cdot 37)$ & $4 \cdot 51(4 \cdot 85)$ & $1.45(1.53)$ \\
\hline$\left[\mathrm{RuH}(\mathrm{CO})\left(\mathrm{PPh}_{3}\right)_{2}(\right.$ ohyac-an $\left.)\right]$ & Green & 147 & $67 \cdot 56(67.98)$ & $3.96(4.33)$ & $1.23(1.58)$ \\
\hline$\left[\mathrm{RuH}(\mathrm{CO})\left(\mathrm{PPh}_{3}\right)_{2}\right.$ (ohyac-oman)] & Brown & 176 & $69.78(71.05)$ & $4 \cdot 76(5 \cdot 16)$ & $1.27(1.59)$ \\
\hline$\left[\mathrm{RuH}(\mathrm{CO})\left(\mathrm{PPh}_{3}\right)_{2}\right.$ (ohyac-pman $\left.)\right]$ & Green & 162 & $69.85(71.05)$ & $4 \cdot 98(5 \cdot 16)$ & $5 \cdot 27(5 \cdot 16)$ \\
\hline$\left[\mathrm{RuCl}(\mathrm{CO})\left(\mathrm{AsPh}_{3}\right)_{2}(\right.$ ohyac-an $\left.)\right]$ & Green & 153 & $61 \cdot 89(62 \cdot 10)$ & $4 \cdot 07(4 \cdot 19)$ & $1 \cdot 16(1.42)$ \\
\hline$\left[\mathrm{RuCl}(\mathrm{CO})\left(\mathrm{AsPh}_{3}\right)_{2}(\right.$ ohyac-oman $\left.)\right]$ & Brown & 168 & $62 \cdot 18(62 \cdot 37)$ & $4 \cdot 17(4 \cdot 42)$ & $1.06(1.39)$ \\
\hline$\left[\mathrm{RuCl}(\mathrm{CO})\left(\mathrm{AsPh}_{3}\right)_{2}(\right.$ ohyac-pman $\left.)\right]$ & Green & 176 & $62 \cdot 08(62 \cdot 37)$ & $4.09(4.42)$ & $1.02(1.39)$ \\
\hline$\left[\mathrm{RuCl}(\mathrm{CO})\left(\mathrm{PPh}_{3}\right)(\mathrm{py})(\right.$ ohyac-an $\left.)\right]$ & Green & 210 & $63 \cdot 70(63 \cdot 90)$ & $4 \cdot 08(4 \cdot 37)$ & $3.78(3.92)$ \\
\hline$\left[\mathrm{RuCl}(\mathrm{CO})\left(\mathrm{PPh}_{3}\right)(\mathrm{py})(\right.$ ohyac-oman $\left.)\right]$ & Brown & 143 & $64 \cdot 08(64 \cdot 14)$ & $4 \cdot 51(4 \cdot 69)$ & $3.67(3 \cdot 80)$ \\
\hline$\left[\mathrm{RuCl}(\mathrm{CO})\left(\mathrm{PPh}_{3}\right)(\mathrm{py})(\right.$ ohyac-pman $\left.)\right]$ & Green & 180 & $63.69(64 \cdot 14)$ & $4 \cdot 32(4 \cdot 69)$ & $3 \cdot 35(3 \cdot 80)$ \\
\hline$\left[\mathrm{RuCl}(\mathrm{CO})\left(\mathrm{PPh}_{3}\right)(\right.$ pip $)($ ohyac-an $\left.)\right]$ & Green & 205 & $63 \cdot 01(63 \cdot 28)$ & $5 \cdot 01(5 \cdot 17)$ & $3 \cdot 50(3 \cdot 88)$ \\
\hline$\left[\mathrm{RuCl}(\mathrm{CO})\left(\mathrm{PPh}_{3}\right)(\mathrm{pip})(\right.$ ohyac-oman $\left.)\right]$ & Brown & 142 & $63 \cdot 46(63 \cdot 61)$ & $5 \cdot 17(5 \cdot 47)$ & $3 \cdot 55(3 \cdot 80)$ \\
\hline$\left[\mathrm{RuCl}(\mathrm{CO})\left(\mathrm{PPh}_{3}\right)(\right.$ pip $)($ ohyac-pman $\left.)\right]$ & Green & 172 & $63 \cdot 45(63 \cdot 61)$ & $5 \cdot 19(5 \cdot 47)$ & $3 \cdot 56(3 \cdot 80)$ \\
\hline
\end{tabular}

*Decomposition

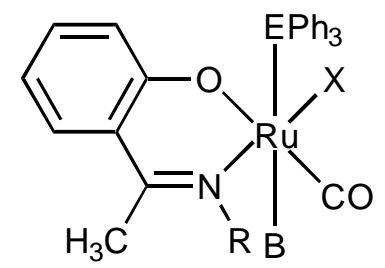

$\left(\mathrm{R}=\mathrm{Ph}, 2-\mathrm{MeC}_{6} \mathrm{H}_{4}\right.$ or $4-\mathrm{MeC}_{6} \mathrm{H}_{4} ; \mathrm{B}=\mathrm{EPh}_{3}$, py or pip; $\mathrm{E}=\mathrm{P}$ or $\mathrm{As} ; \mathrm{X}=\mathrm{H}$ or $\mathrm{Cl}$ )

Scheme 3. Proposed structure of ruthenium(II) complexes.

charge-transfer transition arising from the excitation of an electron from the metal $t_{2 g}$ level to the unfilled molecular orbitals derived from the $\pi^{*}$ level of the ligands, in accordance with the assignments made for other similar octahedral ruthenium(II) complexes. $^{13-15}$

\section{$3.3{ }^{l} H$-NMR spectra}

Coordination of the Schiff bases in the new ruthenium(II) complexes is further confirmed by ${ }^{1} \mathrm{H}$ NMR spectra. The peak observed at $1.65 \mathrm{ppm}$ has been assigned to the methyl group of the Schiff base ligands. The signal for aromatic protons appears as multiplets in the 8.49-6.02 ppm region in all the complexes. In the hydrido complex, $[\mathrm{RuH}(\mathrm{CO})$ $\left(\mathrm{PPh}_{3}\right)_{2}$ (ohyac-an)], the metal hydride signal corresponding to one proton has been observed as a singlet in the very high upfield region $(-12.04 \mathrm{ppm})$.
On the basis of elemental analyses, IR, electronic, and ${ }^{1} \mathrm{H}-\mathrm{NMR}$ spectral data, the following octahedral structure (scheme 3 ) has been tentatively proposed for all the new ruthenium(II) complexes.

\section{Conclusion}

Ruthenium(II) complexes containing monobasic bidentate Schiff bases and triphenylphosphine/triphenylarsine were synthesized and characterized by analytical and spectral techniques. These complexes exhibited catalytic activity in the oxidation of alcohols using $\mathrm{N}$-methylmorpholin-N-oxide as co-oxidant.

\section{References}

1. Reimers J R and Hush N S 1990 Inorg. Chem. 293686

2. Kureshy R I, Khan N H and Abdi S H R 1995 J. Mol. Catal. 96117

3. El-Hendawy A M, Alkubaisi A H, El-Ghany, ElKourashy A and Shanab M M 1993 Polyhedron 122343

4. El-Hendawy A M, El-Ghany, El-Kourashy A and Shanab M M 1992 Polyhedron 11523

5. Bhowon G, Li Kam, Wah H and Narain R 1999 Polyhedron 18341

6. Vogel A I 1989 Textbook of practical organic chemistry 5th edn (London: ELBS)

7. Ahmed N, Levison J J, Robinson S D and Uttley M F 1974 Inorg. Synth. 1548

8. Sanchez-Delgado R A, Lee W Y, Choi S R, Cho Y and Jun M J 1991 Transition Met. Chem. 16241

9. Gopinathan S, Unny I R, Deshpande S S and Gopinathan C 1986 Indian J. Chem. A25 1015 
10. Khera B, Sharma A K and Kaushik N K 1983 Polyhedron 21177

11. Karvembu R, Hemalatha S, Prabhakaran R and Natarajan K 2003 Inorg. Chem. Commun. 6486

12. Viswanathamurthi P, Dharmaraj N, Anuradha S and Natarajan K 1998 Transition Met. Chem. 23337
13. Karvembu R and Natarajan K 2002 Polyhedron 21 219

14. Karvembu R and Natarajan K 2002 Polyhedron 21 1721

15. Natarajan K, Poddar R K and Agarwala U 1977 J. Inorg. Nucl. Chem. 39431 